\title{
American College of Physicians
}

National Cancer Institute

\section{Source}

National Cancer Institute. American College of Physicians. NCI Thesaurus. Code C39312.

A national medical society for internal medicine professionals. It publishes 'Annals of Internal Medicine'. 